\title{
A MAROSVÁSÁRHELYI MAGYAR-ROMÁN VISZONY A TOPONÍMIAI TÁJKÉP TÜKRÉBEN
}

\author{
HOLÁNYI ÁKOS \\ THE HUNGARIAN-ROMANIAN RELATIONSHIP IN TÂRGU MURES \\ IN THE LIGHT OF THE SYMBOLIC LANDSCAPE
}

\begin{abstract}
In the past years, the relationship between Transylvanian Hungarians and Romanians has been stressed by symbolic conflicts that revolved around the Hungarians' use of their minority language and symbols. These conflicts are more pronounced in ethnically mixed cities where Hungarians are still living in significant numbers. This paper analyses one such city, Târgu Mureş, from the perspective of critical toponymy. It studies how efficiently local Hungarian and Romanian symbols are inscribed onto the toponymic landscape, as well as what kind of nationalisms they suggest. Drawing on theoretical insights from nationalism studies and critical toponymic research, the study interprets empirical data based on the analysis of street names, educational institution names and the bilingualism of street name signs. On the one hand, the paper concludes that Romanian symbols are overrepresented in the toponymy. On the other hand, it suggests that local Romanian nationalism has a nationalising character whereas local Hungarian nationalism seems to be more local patriotic in nature.
\end{abstract}

Keywords: critical toponymy, street name, symbolic conflict, nationalism, Târgu Mureş

\section{Bevezetés}

Az elmúlt években több magyar tanulmány foglalkozott városok és térségek szimbolikus tájainak történelmi változásaival (BARTOS-ELEKES Zs. 2016; BOTTLIK Zs. 2017, 2018; BAROCH Cs.-BERKI M. 2018; BAROCH Cs. 2019) és kortárs politikai vitáival (ERŐss Á.-TÁTRAI P. 2010; ERőss Á. 2017). Jelen dolgozat ez utóbbi írások sorába illeszkedik, mert az elmúlt években számos nemzetiségi konfliktus középpontjába került Marosvásárhely kortárs szimbolikus politikai erőviszonyainak megértéséhez járul hozzá a helyi névrajz tanulmányozásával. Figyelembe véve a városi szimbolikus táj fontos szerepét az identitások és lojalitások kialakításában és megőrzésében (AZARYAHU, M. 1996; MitcheLL, K. 2003), valamint a romániai közterületek körüli viták etnikai-nemzetiségi jellegét (DRAGOMAN, D. 2011), a helyi nemzetiségek szimbolikus kezdeményezései megágyaznak az etnikai konfliktusoknak. Az ügyek politikai-társadalmi jelentősége ellenére a marosvásárhelyi szimbolikus konfliktusok eddig csak egy kutatás tárgyát képezték. GYöRGY V.I. (2011) Marosvásárhely köztereinek Bernády György volt polgármester emlékét felhasználó magyar birtokbavételét elemezte a rendszerváltás utáni években. Munkája ellenére számos megválaszolatlan kérdés marad például a magyar és román szimbólumok egymáshoz való aránya, elhelyezésüket övező politikai csatározások és a nagyközönség általi fogadtatásuk terén. Jelen tanulmány ezen tudáshiány enyhítéséhez szeretne hozzájárulni. Elemzésem kiterjed az utca- és oktatási intézményhálózat neveire, valamint az utcanévtáblák kétnyelvűségének jelenlegi helyzetére. Felhasználva a kortárs nacionalizmus-kutatás és a kritikai toponímia eredményeit, megvizsgálom a helyi magyar és román szimbólumok politikai jellemzőit és politikai erőviszonyait, illetve összehasonlítom a marosvásárhelyi helyzetet az országos szinten tapasztaltakkal.

Először röviden összefoglalom a téma szempontjából releváns elméleti előzményeket, rávilágítva a szimbolikus tájkép részét képező toponímia és a nacionalizmus banális megnyilvánulási formái közötti szoros kapcsolatra. Az esettanulmány hátterének rövid bemuta- 
tása után a módszertani fejezetben megtárgyalom az adatgyưjités és -elemzés módszertani nehézségeit s a rájuk adott válaszaimat. Az értekezésben a magyar és román szimbólumok reprezentációjának románok számára kedvező aszimmetriájára és a helyi román szimbólumvilág ellentmondásos jellegére fogok rámutatni. Amellett érvelek, hogy a marosvásárhelyi szimbolikus politizálás terén mutatott nemzetiségi erőviszonyok helyi szinten megerősítik a magyar kisebbség helyzetét elemző korábbi tanulmányok eredményeit.

\section{A szimbolikus tájak politikája}

A posztmodern tájmegközelítés alapján a tájat szövegként elemezhetjük. Eszerint a tájkép részét képező képek és szimbólumok koherens egészet alkotnak, melyek rejtett kódok, feltételezések és utalások útján üzeneteket közvetítenek (WYLIE, J. 2007). A táj vizuális elemei a „táj, mint szöveg” jelei, amelyek rendszerbe foglalva különböző hatalmi elbeszélésmódok részeivé válnak. Vagyis a tájkép a hatalom ideológiával átitatott kifejeződése, mely általában észrevétlenül fejti ki hatását (ToLIA-KELLY,D.P. 2013). A táj szövegként való felfogása számos értelmező elemzést tesz lehetővé. WYLIE, J. (2007) a következő kérdéseket javasolja irányvezetőnek: Milyen domináns olvasatokat fejeznek ki az elitdiskurzusok? Ki vagy kik a táj szerzői? Milyen története(ke)t mesél el a táj? Hogyan fogják olvasni? A tájba kódolt üzenet könnyen érthető vagy különleges tudás szükségeltetik megértéséhez? Bár mindezen kérdések megválaszolása túlmutat dolgozatom keretein, némelyikük átdolgozásával felfedhetjük a névrajz szerzőinek szimbolikus prioritásait. Államférfiakat és hadvezéreket, vagy tudósokat és múvészeket részesítenek előnyben? Vannak nagyformátumú helyi kötődésú emberek akikre büszkék a városi toponímia alakítói? Ugyanolyan preferenciákról árulkodnak-e a magyar és a román nevek?

A szimbolikus tájképek és a nacionalizmus kapcsolatát először COHEN és KLIOT (1992) mutatta be. A nacionalizmus kifejeződésében a különböző helyek reprezentációja, szimbólumvilága fontos szerepet tölt be. Egyrészt az emberek a lokalitások által találkoznak a nemzettel és értelmezik azt (JONES, R.-DESFORGES, L. 2003), másrészt a helyek sajátosságai képesek kifejezni a nemzet sokszínúségét és a nemzethez tartozás számos különböző módját (JONES, R.-FOWLER, C. 2007). Elemzői szempontból a helyi lépték megvizsgálása mindemellett fontos információkkal szolgálhat a társadalmi folyamatok és a banális nacionalizmus, illetve az országos és helyi nacionalista politizálás kapcsolatainak megértéséhez (Jones, R.-Desforges, L. 2003; Jones, R.-Fowler, C. 2007).

BRUBAKER, R. (1996) szerint Európában három különböző nacionalizmus létezik egymással kölcsönös és dinamikusan változó viszonyban: nemzetiesítő nacionalizmus, kisebbségi nacionalizmus és külső anyaországi nacionalizmus. A nemzetiesítő nacionalizmus célja egy egységes, homogén nemzetállam létrehozása, míg a másik kettőé ennek megakadályozása. A nemzetiesítő nacionalizmus azonban szubjektív megítélésú, amit a nacionalizmus banális megnyilvánulási formái szemléltetnek. BILLIG, M. (1995) megfogalmazásában a banális nacionalizmus a nacionalizmus hétköznapi, közönséges kifejeződése. Billig példaként említi a nemzethez kapcsolódó fogalmak és jelképek hétköznapi használatát, melyek fontosak „A nemzetállamok reprodukciójához [ami] a kollektív emlékezés és felejtés dialektikájától, valamint a képzeletétôl és a fantáziátlan ismétléstôl függ”. Ugyanakkor a domináns nemzetiség banális nacionalizmusa a kisebbségek számára a forró nacionalizmus zavaró és felkavaró megnyilvánulásai s az elnyomás jelképei lehetnek (MERRIMAN, P.-JONES, R. 2009; Jones, R.-Merriman, P. 2009). Tehát a domináns nemzetiségnek nem kell tudatosan homogenizálódásra törekednie ahhoz, hogy azt a kisebbség és/vagy az annak nevében eljáró anyaország annak értékelje (BRUBAKER, R. 1996). 
A magyar-román szimbolikus vetélkedések kategorizálásához HARRISON, S. (1995) elmélete ad támpontot. Harrison szerint a szimbolikus konfliktusoknak négy fajtája van, melyek a valóságban valamilyen kombinációban jelennek meg. E négy típus az értékelési verseny, amiben a szimbólumok értéke a tét; a tulajdonlási verseny, amiben több csoport küzd a szimbólum kizárólagos birtoklásáért; az innovációs verseny, amiben új szimbólumok létrehozása áll a konfliktus középpontjában; és a terjeszkedési verseny, amiben egymás szimbólumainak kicserélése a tét. Ezek közül az értékelési, a tulajdonlási és a terjeszkedési versenyek közvetlenül más csoport(ok) szimbólumokra épülő politikai tőkéjének rombolásáról szólnak, míg az innovációs verseny mindezt közvetetten, a régiek új szimbólumokkal való háttérbe szorításával éri el.

A szimbolikus tájkép elemei politikai jelentőséggel bírnak. Az általam vizsgált utcanevek alacsony szimbolikus töltetű tájelemek, mert gyakorlati szerepük elhomályosítja szimbolikus-ideológiai szerepüket (AZARYAHU, M. 2009). Az utcanevek társadalmi-szemiotikai hatalma abban rejlik, hogy a társadalmi valóságot egyszerre számos narratíván keresztül befolyásolják (napi tájékozódás, turisztikai kiadványok stb.) (AZARYAHU, M. 1996), észrevétlenül közvetítve az alkotó/megrendelő társadalmi és politikai elképzeléseit (MITCHELL, K. 2003). Mindennapi használat során az utcanevek történelmi jelentése fokozatosan elhalványul, helyét földrajzi megjelölés váltja fel. Ez azt jelenti, hogy „az egyének által a helynevekhez rendelt és társitott jelentés nagymértékben annak is függvénye, hogy a személyes élmények miként határozzák meg a tájjal való szemiotikus kapcsolatukat" (RoseREDWOOD, R. et al. 2010 p. 459). Ugyanakkor a történelmi utcanevek földrajzivá válása egyben erôsíti is erejüket, ugyanis a beléjük rejtett múltértelmezés földrajzi formában magától értetődónek és természetesnek hat (AzARYAHU, M. 2009).

A gondosan megkoreografált táj képisége kijelöli a mindennapi emlékezet koordinátáit, azokat a helyeket, amiken keresztül elhelyezhetjük és elmesélhetjük a múltat és jelenbéli identitásunkat (TOLIA-KELlY, D.P. 2013). Azonban a táj megkoreografáltsága azt is jelenti, hogy a múltról szelektív képet ad. A modern világban az emlékezet nem csak úgy magatehetetlenül létezik, azt intézmények, történészek, átlagos polgárok aktívan használják és kihasználják, illetve visszaélnek vele céljaik elérése érdekében (SAID, E. 2000). Emiatt az örökség nemcsak kulturális, hanem politikai eszköz is, amelyet bizonyos csoportok manipulálnak álláspontjuk támogatása vagy ellenfeleik aláásása végett (MCDowELL, S. 2008).

Az emlékezet helyei körüli viták ezért az emlékezetpolitika szerves részei, melynek tétje, hogy melyik társadalmi csoportnak a történelem értelmezése lesz uralkodó a köztereken (TILL, K.E. 2003). Azonban az emlékezet helyei nem az élő társadalmi emlékeket örökítik meg, hanem történelmet alkotnak. A történelem egyetlen nézőpontot tükröző, félkész rekonstrukciója a múltnak, amely ennek ellenére egyetemes tekintélyt követel magának (NoRA, P. 1989). Ezáltal az uralkodó történelemváltozatot megörökítő emlékhelyek egyszerre az egységesítés és a felosztás helyei. Az emlékhelyek szimbolikája ugyanis gyakran egy bizonyos csoport érdekeit, identitását fejezi ki, erósítve a csoport tagjainak önazonosságát (MCDowELL, S. 2008). Hasonlóképpen, a szimbolika által meghatározott elbeszélési keretrendszer kijelöli bizonyos ötletek és gyakorlatok „,természetességét”, lehetővé téve egyes, ugyanakkor korlátozva másmilyen jelentéstartalmakat (RAVIO, P. 1998). Ez azonban sokszor kirekeszt vagy megsért más csoportokat (MCDowELL, S. 2008).

\section{Az esettanulmány politikai háttere}

Romániában a legtöbb szimbolikus konfliktus a kétnyelvűség és a magyar szimbólumok (székely zászló, magyar Himnusz stb.) használata körül alakult ki. A romániai magyar 
nyelvhasználat hiányosságaira nemzetközi kisebbségvédelmi egyezmények felügyelő szervei is felfigyeltek. A legfrissebb Románia-jelentések megállapították, hogy (1) a toponímiai többnyelvűség nem korlátozódhat helység és intézménynevekre, magukba kell foglalniuk minden közterület elnevezését is; valamint, (2) hogy a toponímiai többnyelvúség akadályai a helyi adminisztráció szintjén találhatóak (BETHLENDI A.-ToRó T. 2018).

Ennek jó példáját adja a 2011-es népszámlálási adatok alapján 49\%-ban román és 43\%ban magyar lakosságú Marosvásárhely (Erdélyi Magyar Adatbank n.d.). A településen az 1990. évi „fekete március” véres etnikai összetúzései óta a megszokottnál feszültebb légkör uralkodik (LÁszló M.-NovÁK Cs. Z. 2012), amely hatással van a szimbolikus politizálásra. Az 1990-es évekbeli magyar emlékmúállításokat a románok ellenséges magyar térfoglalásként értelmezték, ezért a helyi hatalom 2000-ben történő megszerzése óta minden magyar szoborral együtt egy román szobrot is fel kellett állítani, továbbá a város főterén egészen 2020. novemberéig csak román kötődésű szobrok álltak (GYÖRGY V. I., 2011). Újabban a szimbolikus konfliktusok központjában a kétnyelvú utcanévtáblák találhatók, melyet a marosvásárhelyi székhelyú magyar Civil Elkötelezettség Mozgalom (CEMO) karolt felt. A szervezet 2007 óta számos pert és kezdeményezést indított a törvények és nemzetközi szerződések által előírt oktatási és közigazgatási kétnyelvűség helyi biztosítása érdekében. Pereket indítottak a valóban kétnyelvú utca- és intézménynévtáblák kihelyezése miatt (CEMO 2014, 2017) valamint nem hivatalos magyar nyelvű utcanévtáblákat helyeztek ki a román nyelvú táblák alá (Maszol, 2015).

Összességében Marosvásárhelyen adott három tényező, amik kutatásom szempontjából kiemelik a várost a többi romániai magyar kisebbséggel rendelkező település közül. Egyrészt, mivel a magyarok és a románok közel egyenlő arányban lakják a várost, nem lehet a magyar szimbólumok esetleges alacsony reprezentációját a román lakosság demokratikus döntésének tulajdonítani. Míg más városok esetében ez egy kézenfekvő magyarázatként kínálkozik, Marosvásárhely esetében egyértelmúen más hatalmi struktúrák okozzák a szimbolikus konfliktusokat. Másrészt 1990. évi ,fekete márciusának” emléke nehezebbé teszi a magyarság számára fontos szimbolikus politika célok elérését, mint más városokban. Harmadrészt itt székel a kétnyelvú utcatáblákért és adminisztrációért küzdő CEMO, amely munkásságának eredménye az utcanévtáblák ügyének hangsúlyos megjelenése az erdélyi sajtóban és közéletben.

\section{Módszertani problémák}

Az empirikus elemzésem egyrészről az utca- és oktatási intézménynevek jellemzőinek feltárásából, másrészt az utcanévtáblák kétnyelvűségének megvizsgálásából áll. Az utcák listáját és típusát a hivatalos utcanévmutatóból nyertem ki. Az utcákat és oktatási intézményeket névadójuk típusa, földrajzi kötődése, foglalkozása, nemzetisége és politikai hozzáállása alapján jellemeztem (1. táblázat). A névadó személyek és események hozzáállásának megállapításához számos újságcikket, történészi véleményt és ismeretterjesztő weboldalt használtam fel, ugyanakkor a végső döntésemet több esetben befolyásolta szubjektív megítélésem is. Például Dózsa Györgyöt a mindkét nemzetiség számára fontos személyeket jelentő 1-es kategóriába osztottam be, míg Hunyadi Mátyást „csak” a 2-esbe, annak ellenére, hogy mindkét nemzet nacionalista történetírása saját hősének tekinti. Mérlegelésem szerint ugyanis Hunyadi Mátyás, mint román hős, nem elég elterjedt román diskurzusokban. Elismerve azonban, hogy az ilyen döntések erősen támadhatók, az adatok bemutatása és egyszerű statisztikai elemzése után az ötosztatú nominális skála helyett egy háromosztatú ordinális skálát használtam az adatok további értelmezése során. 
Ez csökkenti a szubjektív besorolásból fakadó hibák valószínűségét. Az ordinális skálán megkülönböztetek konszolidáló, együttmúködést elősegítő $(1,2)$; semleges (3); és ellentmondásos $(4,5)$ neveket. Összességében 462 utcát és 41 oktatási intézményt vizsgáltam meg. Közülük csak a személy- és eseménynevekkel rendelkező utcákat és intézményeket elemeztem részletesen, mert nem lehet objektíven megállapítani, hogy az egyéb típusok esetében melyik utcanevek rendelkeznek szimbolikus politikai tartalommal.

1. táblázat - Table 1

Az utcanevek elemzésekor használt szempontok

The characteristics used for the analysis of street names

\begin{tabular}{|c|c|c|}
\hline Kategória & Definíció & Értékek \\
\hline Típus & $\begin{array}{l}\text { Miról van elnevezve } \\
\text { az utca? }\end{array}$ & $\begin{array}{l}\text { Esemény, köznév, földrajzi név, melléknév, } \\
\text { személynév }\end{array}$ \\
\hline Földrajz & $\begin{array}{l}\text { Földrajzilag milyen } \\
\text { kötődésû? }\end{array}$ & $\begin{array}{l}\text { Helyi (Maros megyéhez köthető), } \\
\text { erdélyi (kiterjedt értelemben vett erdélyhez köthető), } \\
\text { országos (Erdélyen kívüli történelmi Magyar- } \\
\text { országhoz vagy Nagy-Romániához köthető), } \\
\text { külföldi }\end{array}$ \\
\hline Foglalkozás & $\begin{array}{l}\text { Milyen tevékenységi } \\
\text { területhez köthető? }\end{array}$ & $\begin{array}{l}\text { Politika (politikusok, uralkodók, hadvezérek), } \\
\text { irodalom, múvészet, tudomány, sport }\end{array}$ \\
\hline Nemzetiség & $\begin{array}{l}\text { Milyen nemzetiség- } \\
\text { hez köthető? }\end{array}$ & $\begin{array}{l}\text { Közös (magyar és román), magyar, román, német, } \\
\text { orosz, francia, nemzetközi }\end{array}$ \\
\hline Hozzáállás & $\begin{array}{l}\text { A magyar-román } \\
\text { kapcsolatokat az } \\
\text { együttmúködés vagy } \\
\text { az ellenségeskedés } \\
\text { felé tereli? }\end{array}$ & $\begin{array}{l}1 \text { (mindkét nemzetiség számára egyformán pozitív } \\
\text { és fontos) } \\
2 \text { (inkább egyik nemzetiség számára fontos pozitív) } \\
3 \text { (egyik számára pozitív, másik számára közömbös) } \\
4 \text { (egyik számára pozitív, másik számára enyhén } \\
\text { negatív vagy múltbeli etnopolitikai ellenfél) } \\
5 \text { (egyik számára pozitív, másik számára erősen } \\
\text { negatív) }\end{array}$ \\
\hline
\end{tabular}

Kutatásomba beemeltem a marosvásárhelyi utcanévtáblák vizsgálatát is, tekintve, hogy ezek fontos eszközei a nacionalista emlékezetpolitikának, mert a többnyelvú táblák menynyiségi és minőségi jellemzői hasznos indikátorai lehetnek a nemzetiségek relatív politikai hatalmának és egymáshoz való hozzáállásának (Jones, R.-MERRIMAn, P. 2009; MERRIMAN, P.-JonEs, R. 2009; AzARYAHU, M. 2012). Így az adatgyújtés során Google utcaképek segítségével megszámoltam Marosvásárhely utcanévtábláit, kategorizálva ôket aszerint, hogy a közterület neve és fajtája (utca, tér, sétány stb.) egy vagy két nyelven van-e feltüntetve.

Az adatgyuujjtés és -feldolgozás során az alábbi nehézségekkel szembesültem. Először is, az utcák közel harmadához nem tudtam adatot rendelni. 63 eseteben (13,6\%) a vizsgált utca nem rendelkezett egyetlen észlelhető utcanévtáblával sem, míg 79 esetben (17\%) az utcáról nem volt elérhető Google utcakép az adatgyújtési időszakban (2020. július 13-25.). Ezek azonban jellemzően rövid vagy periférikus utcák (1. ábra), amik alacsony szimbolikus politikai jelentőséggel bírnak. Másodszor, esetenként problémás volt az utcanévtáblák elolvasása vagy megtalálása is. A széles utak és körutak esetében a képkészítés és az utcanévtáblák helye közötti távolság, illetve az utakat szegélyező fák takarása miatt valószínúleg néhány utcanévtáblát nem vettem észre. Harmadszor, a felvételek jelen- 
tősen eltéró idôpontban készültek (2. táblázat). A 2012-2019 közötti időszak egybeesik a magyar szervezetek kétnyelvú utcatáblákért folytatott legutóbbi akciósorozataival, így a kutatás szempontjából fontos időszakról van szó. Ezért a 2012-es és 2019-es adatokat összehasonlítandó, egyenlótlen változókat feltételezó t-tesztet végeztem, amely alapján az adathalmazok közötti különbség nem jelentôs ( $\mathrm{p}=0,1923$ a közterület típusának kétnyelvűsége esetében, $\mathrm{p}=0,1499$ az utcanevek kétnyelvűsége esetében), így a továbbiakban a képkészítés dátumával nem foglalkoztam.

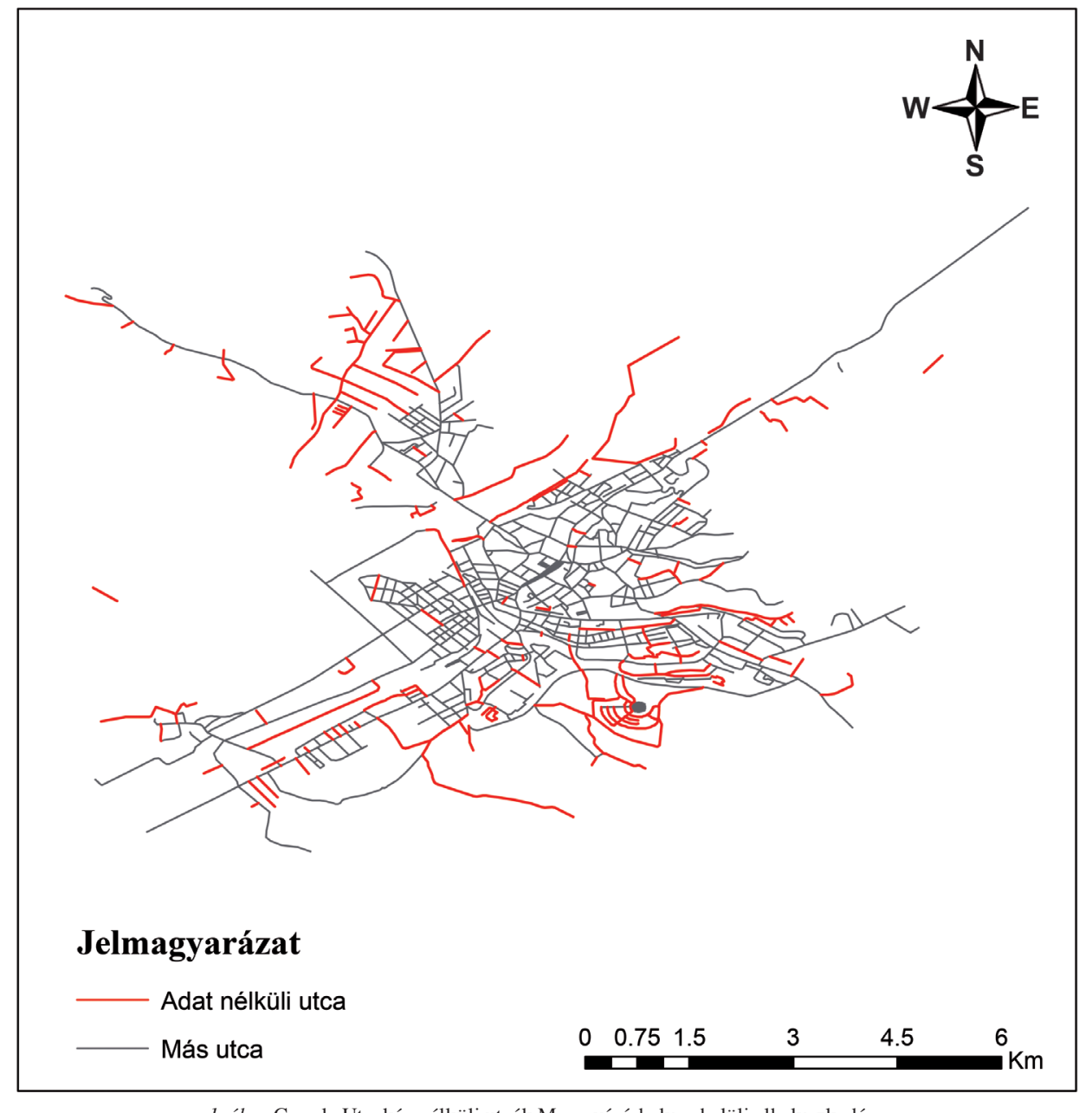

1. ábra Google Utcakép nélküli utcák Marosvásárhelyen belüli elhelyezkedése Figure 1 The position of streets without GSV data within Târgu Mureş

Kutatásomban a szubjektivitás kétféleképpen jelenik meg. Egyrészt az utca- és intézménynevek politikai jelentéstartalmának megállapításakor nem támaszkodhattam az emberek szimbólumokhoz való viszonyát vizsgáló kutatásokra. Jelenleg csak kevés információnk van arról, hogy az erdélyi magyarok hogyan viszonyulnak jeles magyar személyekhez (VERES V. 2005, 2008), ugyanakkor semmit sem tudunk a magyarok és románok 
Marosvásárhelyi utcaképek száma év szerinti lebontásban

a Google Utcaképek adatbázisában

Street images of Targu Mures based on year in the Google Street View database

\begin{tabular}{lc}
\hline Képkészítés dátuma & Utcák száma \\
\hline 2012 & 236 \\
2014 & 8 \\
2018 & 12 \\
2019 & 93 \\
2012,2018 & 5 \\
$2012,2018,2019$ & 1 \\
$2012,2018,2020$ & 1 \\
2012,2019 & 19 \\
2012,2020 & 1 \\
2014,2019 & 3 \\
2018,2019 & 3 \\
\hline
\end{tabular}

egymás jeles személyeiről alkotott véleményéről. Emiatt csak nem mindig biztos hitelú másodlagos forrásokra (tankönyvekre, történészi véleményekre, újságokra és ismeretterjesztő oldalakra) tudtam támaszkodni. E források azonban csak a toponímiában szereplő emlékező nevekről alkotott helyi és nemzeti elit diskurzusokra engednek következtetni, amelyek különbözhetnek a lakosság szimbólumokról alkotott véleményeivel. Másrészt az adatok kiértékelése közben óhatatlanul befolyásolt egyéni szubjektivitásom, mint erdélyi felmenőkkel igen, de erdélyi élettapasztalattal nem rendelkező magyar ember. Ezért előfordulhat, hogy kissé más jelentőséget tulajdonítottam bizonyos névadásoknak, mint ahogyan azt a helyiek tennék.

\section{Marosvásárhely kiegyensúlyozatlan toponímiai tájképe}

\section{A toponímia neveinek általános jellemzói}

Elemzésem arra a feltételezésre épül, hogy egy többnemzetiségú város toponímiája akkor nevezhetô kiegyensúlyozottnak, ha nagyvonalakban a település nemzetiségi arányaihoz hasonló szimbólum-arányok érvényesülnek benne. Természetesen annak megállapítása, hogy mi számít a nemzetiségi arányoktól való jelentős eltérésnek személyenként és körülmények szerint változó lehet. Például nagyszámú, mindkét nemzetiség számára egyformán fontos személy szerepeltetése okozhat jelentős eltérést a toponímia konszolidáló jellegének megtartása mellett. Jelen tanulmányban a demográfiai arányoktól való jelentős eltérést 10 százalékpontos küszöbtől veszem. Megítélésem szerint a tanulmány így elégséges hibahatárral dolgozik ahhoz, hogy megállapításai jelentősek legyenek.

Az utca- és intézménynévi adatok alapján a magyar és román szimbólumok között jelentős mennyiségi és tulajdonságbeli eltérések vannak. Marosvásárhelyen közel kétszer annyi román utca- és több mint ötször annyi román intézménynév van, mint a magyar. Ez jelentős eltolódást jelent a nemzetiségek 49:43-as arányához képest (3. táblázat), mert 
A nemzetiségekhez köthető utcák és intézmények száma és aránya Number and proportion of street and institution names linked to nationality

\begin{tabular}{lcccr}
\hline Névadó nemzetisége & Utcák száma & Aránya & $\begin{array}{c}\text { Intézmények } \\
\text { száma }\end{array}$ & Aránya \\
\hline Magyar & 41 & $32 \%$ & 4 & $15 \%$ \\
Román & 79 & $62 \%$ & 21 & $81 \%$ \\
Egyéb & 8 & $6 \%$ & 1 & $4 \%$ \\
Összesen: & 128 & $100 \%$ & 26 & $100 \%$ \\
\hline
\end{tabular}

eléri a 10 százalékpontos küszöböt. Meg kell jegyezni, hogy az utcanevek esetében alig közelíti meg ezt. Ez tekinthető helyi román részről folytatott terjeszkedési versenynek (vö. HARRISON, S. 1995). Ugyanakkor fontos tisztában lenni azzal, hogy a marosvásárhelyi román szimbólumvilág megteremtésére irányuló törekvések az 1920-as évekig nyúlnak vissza, vagyis számos név évtizedek óta jelen lehet a toponímiában. Emiatt előfordulhat, hogy a nemzetiségi szimbolikus hegemónia megteremtése a névrajzban, ami a terjeszkedése verseny végső célja, már nem hangsúlyos eleme a kortárs szimbolikus politikai vitáknak.

Az utca- és intézménynevek földrajzi kötődésénél, foglalkozásánál és politikai hozzáállásánál is számottevő eltérések tapasztalhatók. Földrajzi kötődésüket tekintve a magyar névadók 88\%-a kötődik Marosvásárhely környékéhez vagy Erdélyhez, míg a román névadóknak csak 53\%-a (2.ábra). Hasonló preferenciák figyelhetők meg az intézménynevek esetében is (4. táblázat). Míg a magyarok a kevés névadási lehetőséget helyi vonatkozású személyekre használták, a román nevú iskolák fele Erdélyen kívüli személy nevét viseli.

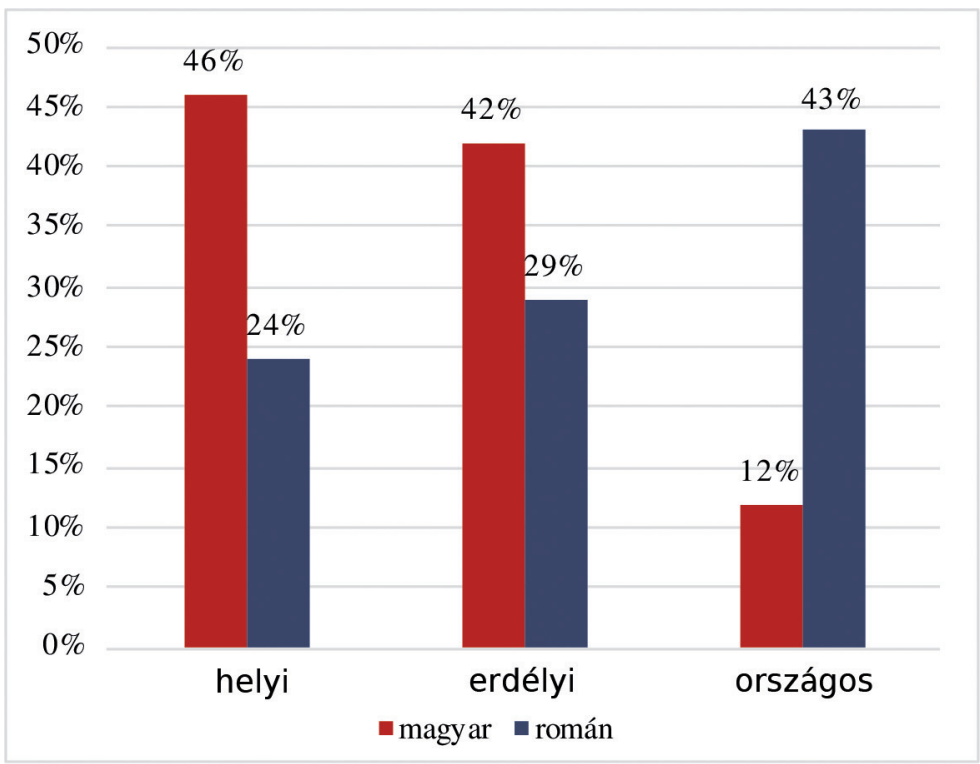

2. ábra Magyar és román utcanevek aránya az összes magyar és román utcanévhez képest földrajzi kötődés alapján (a románok 4\%-ról nem sikerült kideríteni földrajzi kötődésüket)

Figure 2 Proportion of Hungarian and Romanian street names to all Hungarian and Romanian street names based on geography. The geographical connection of $4 \%$ of Romanians is unknown 
Az intézménynevek eloszlása földrajzi és nemzetiségi kötődés alapján The distribution of institution names based on geographic and nationality connections

\begin{tabular}{cc}
\hline Névadó kötődése & Intézmények száma \\
\hline - helyi & 6 \\
magyar & 3 \\
román & 3 \\
- erdélyi & 8 \\
magyar & 1 \\
román & 7 \\
- külföldi & 1 \\
német & 1 \\
- országos & 12 \\
román & 12 \\
Összesen & 27 \\
\hline
\end{tabular}

Ezenkívül, kisebb,ám így is számottevő eltérés figyelhető meg a névadók foglalkozás szerinti eloszlásában. A románok 12\%-kal több politikához köthető személlyel és eseménnyel bírnak az utcanévmixben mint a magyarok, az utóbbiak azonban arányaiban 8\%-kal több tudósról és 5\%-kal több múvészről neveztek el közterületet (3. ábra). A többi kategória esetében a különbség elenyésző. Az intézménynevek esetében hasonló arány összehasonlítást nem tudunk végezni a magyar névadók alacsony száma miatt. A névadási gyakorlat okaira a jelen kutatás adatai alapján nem tudunk következtetni.

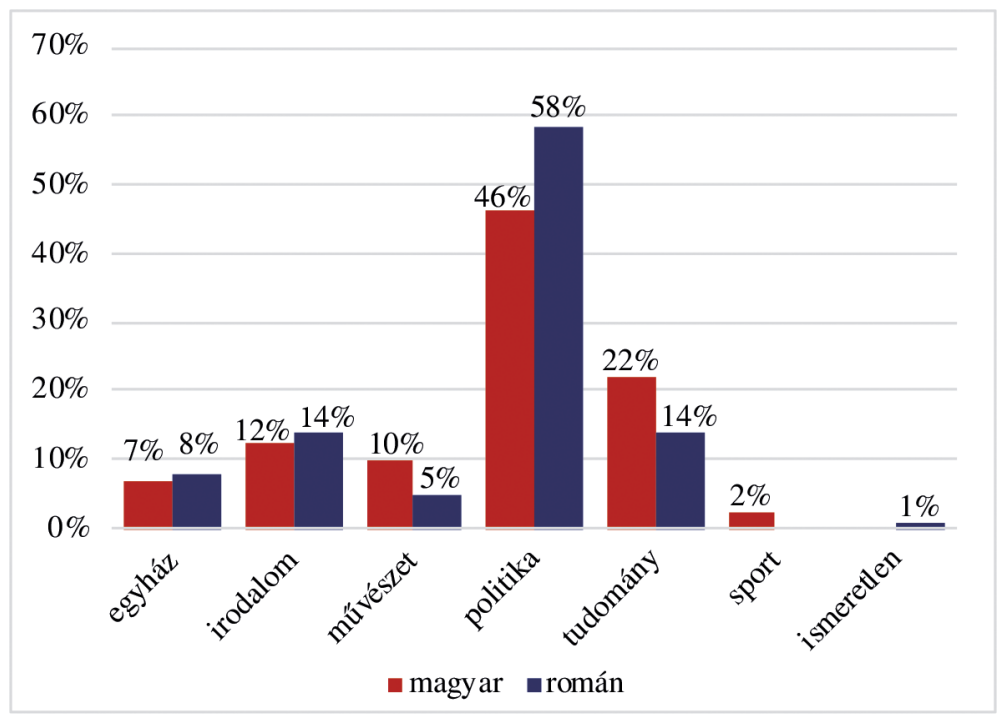

3. ábra A magyar és román kötődésú utcanevek eloszlása foglalkozás szerint az összes magyar és román névadón belül

Figure 3 Distribution of Hungarian and Romanian street names to all Hungarian and Romanian names based on occupation 
Végezetül meg kell említeni a magyar és román szimbolikus nevek politikai hozzáállása közötti különbséget. Statisztikai szemszögből a névelemzés során felállított nominális skála átlaga 2,8976, mediánja 3. Ez azt jelenti, hogy a névhalmaz átlagos hozzáállása enyhén ellentmondásos, ámbár a legtöbb név semleges politikai tartalommal bír a nemzetiségek közötti viszony szempontjából. Bár az etnikumok közötti harmóniát és együttmúködést támogató utcanevek többen vannak, mint az ellentmondásos megítélésúek (4. ábra), az utóbbiak mind kivétel nélkül román nevek (5. ábra), amik így ellentételezik a névmix amúgy enyhén pozitív összképét. Az intézménynevek ugyanezt a mintát követik le, négy együttmúködést elősegítő név (Szász Adalbert, Romulus Guga, Dr Bernády György, Ion Vlasiu) áll szemben három ellentmondásossal, melyek közül az utóbbiak mind román kötődésúek (Dacia, Mihai Viteazul, Avram Iancu). Ugyanakkor a szimbolikus nevek politikai hozzáállásának meghatározásához felhasznált módszer miatt előfordulhat, hogy egyes magyar nevek is az ellentmondásos kategóriába kellene kerüljenek. Ezért elsósorban

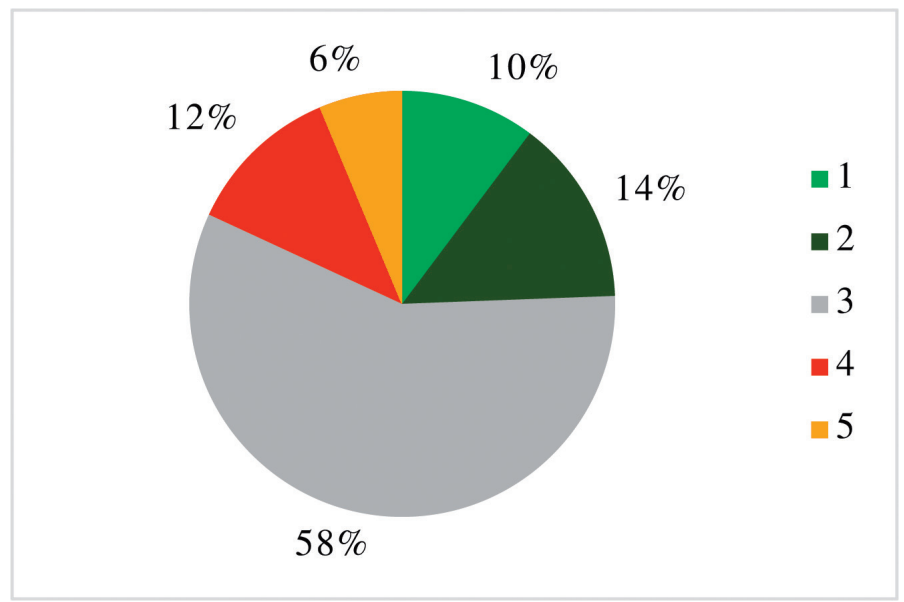

4. ábra Szimbolikus utcanevek eloszlása hozzáállás szerint (1: közös büszkeség; 5: erôsen ellentmondásos)

Figure 4 Distribution of commemorative names based on political attitude (1: most positive; 5: most controversial)

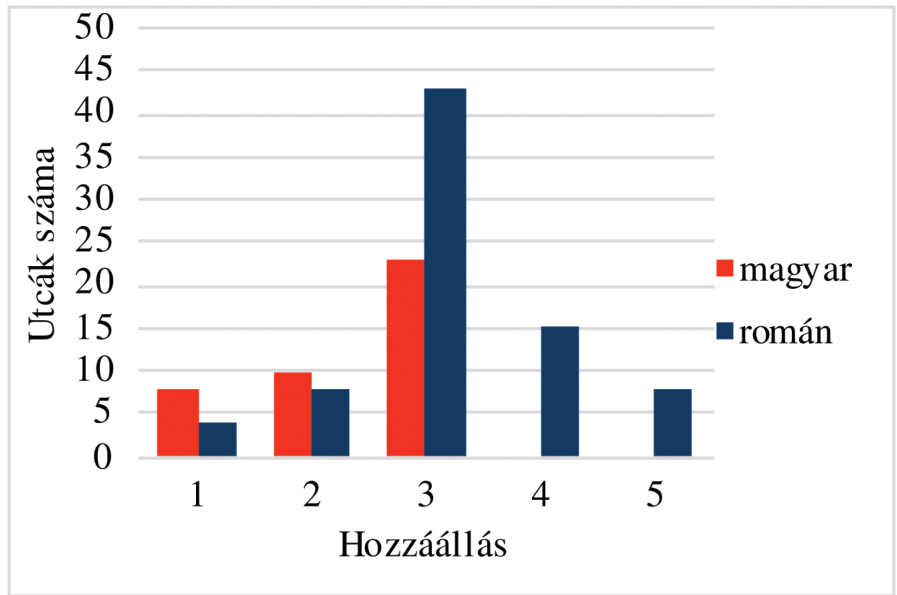

5. ábra Különböző hozzáállású utcák egymáshoz viszonyított száma (1: közös büszkeség; 5: erősen ellentmondásos) Figure 5 Number of streets according to nationality and political attitude (1: most positive; 5: most controversial) 
a magyar és román szimbolikus nevek eloszlásának általános képét tartom fontosnak, nem pedig mindegyikük politikai jelentésének pontos meghatározását. Mindenesetre a mindkét nemzet számára pozitív emlékező nevek enyhe többsége az ellentmondásos nevekkel szemben mindenképpen pozitívumként értékelendő, ugyanis a mindkét nemzet történeti panteonjában szereplő közös hősök kisebbséget képeznek az egymás elleni küzdelmek során érdemeket szerzőkhöz képest (ZAHORÁN Cs. 2016). Mint látható, a helyi román és magyar utca- és intézménynévi panteon elég eltérő tulajdonságokkal rendelkezik, ezért érdemesebb egy kicsit közelebbról is megnézni, hogy mit árulnak el a nemzetiségi elitek helyi önképéről és a román-magyar viszonyról.

\section{A konszolidáció toponímiai lenyomatai}

Amint azt az 5. táblázat is mutatja, a jó nemzetiségi viszonyt támogató nevek között vegyesen találhatunk magyar és román névadókat, valamint valamennyi foglalkozási csoport képviselőjét, míg a feszültségkeltő neveket a román nemzetiségú, politikához kötődő személyek uralják.

5. táblázat-Table 5

A román és magyar szimbolikus nevek eloszlása hozzáállás

és foglalkozás szerint csoportosítva

Categorisation of Romanian and Hungarian symbolic names based on attitude and occupation

\begin{tabular}{|c|c|c|c|c|c|c|}
\hline \multirow{2}{*}{$\begin{array}{l}\text { Névadó } \\
\text { hozzáállása } \\
\text { foglalkozás } \\
\text { szerint } \\
\end{array}$} & \multicolumn{3}{|c|}{ román } & \multicolumn{3}{|c|}{ magyar } \\
\hline & $\begin{array}{l}\text { Utcák } \\
\text { száma }\end{array}$ & $\begin{array}{l}\text { Intézmények } \\
\text { száma }\end{array}$ & Összesen & $\begin{array}{l}\text { Utcák } \\
\text { száma }\end{array}$ & $\begin{array}{c}\text { Intézmények } \\
\text { száma }\end{array}$ & Összesen \\
\hline 1 & 4 & & 4 & 8 & 1 & 9 \\
\hline politika & 3 & & 3 & 6 & & 6 \\
\hline sport & & & & 1 & 1 & 2 \\
\hline tudomány & 1 & & 1 & 1 & & 1. \\
\hline 2 & 8 & 2 & 10 & 10 & 1 & 11 \\
\hline egyház & & & & 2 & & 2 \\
\hline irodalom & 1 & 1 & 2 & & & \\
\hline művészet & 2 & 1 & 3 & 1 & & 1 \\
\hline politika & 3 & & 3 & 4 & 1 & 5 \\
\hline tudomány & 2 & & 2 & 3 & & 3. \\
\hline 3 & 43 & 17 & 60 & 23 & 2 & 25 \\
\hline egyház & 5 & & 5 & 1 & & 1 \\
\hline irodalom & 10 & 4 & 14 & 5 & & 5 \\
\hline múvészet & 2 & 1 & 3 & 3 & & 3 \\
\hline politika & 18 & 5 & 23 & 9 & 1 & 10 \\
\hline tudomány & 8 & 7 & 15 & 5 & 1 & 6 \\
\hline 4 & 15 & 2 & 17 & & & \\
\hline egyház & 1 & & 1 & & & \\
\hline politika & 14 & 1 & 15 & & & \\
\hline egyéb & & 1 & 1 & & & \\
\hline 5 & 8 & 1 & 9 & & & \\
\hline politika & 8 & 1 & 9 & & & \\
\hline
\end{tabular}


A konszolidáló nevek között két tematikus csoportot lehet kiemelni. Az egyes kategória tematikus csoportját az 1989-es forradalomnak emléket állító magyar és román nevek alkotják. A 12 idetartozó névből hat helyi mártíroknak állít emléket, míg egy Ceaușescu menekülését, az 1989-es forradalom napját (Str. 22 Decembrie 1989) örökíti meg. Ez arra utal, hogy a rendszerváltást mindkét nemzetiség egy fajta közös erőfeszítés eredményének éli meg, erősítve a nemzetiségek közötti szolidaritást. Ez különösen jelentős a 1990. évi ,fekete márciusának" tükrében, mely hosszú idő óta mérgezi a helyi magyar-román kapcsolatokat. Eredményességüket azonban csökkenti, hogy az 1989. december 22-e utca kivételével rövid, periférikus utcák viselik nevüket, melyek nem alkalmasak a helyi kollektív emlékezet eredményes befolyásolására nevük ritka használatuk miatt (vö. AZARYAHU, M. 1996). Hasonló szerepet töltenek be a kettes kategóriában az 1974-es árvíz védelmében szerepet vállaló román őrnagyok, Ionel Giurchi, Lazăr Blejnari és Mircea Robu. Konszolidáló szerepüket azonban nagyban csökkenti alacsony ismertségük és a kommunista román karhatalomhoz való kötődésük.

Ezek mellett találhatók olyan konszolidáló történelmi személyek is, akik nemzetiségi hovatartozását értelmiségi vita övezi. Ide tartozik: Dózsa Görgy, Kinizsi Pál és I. (Hunyadi) Mátyás magyar király. E személyeket mind a magyar, mind a román nemzeti történetírás és véleményformálók magukénak tartják, gyakran kizárólagos alapon (pl. KÁDÁR GY. 2011; TohaneAnu, T. 2017). Az eltérő hozzáállás különösen Mátyás király esetében szembetűnő, ugyanis a Hunyadi család havasalföldi, feltehetőleg etnikailag román származása miatt alkalmas lehetne a közös ünneplésre, szemben az etnikailag zömében magyarokhoz sorolt Dózsa és Kinizsi személyeivel. A kisajátító hozzáállás miatt a fellépő szimbolikus konfliktus HARRISON, S. (1995) felosztásában tulajdonlási versenynek tekinthető, hiszen a felek egyetértenek a szimbólumok presztízsében, de vitatják hovatartozásukat.

Erre jó példa a város egyik főútjának nevet adó Dózsa György személye, aki körül mind a magyarok, mind a románok körében kultusz épült. Bár ennek gyökerei a kora 20. századi népi mozgalmakig nyúlnak vissza, kiteljesedése a kommunista történetíráshoz köthető. Mind a magyarországi, mind a romániai kommunista propaganda Dózsát kegyetlenül meggyilkolt parasztvezérnek mutatta be, saját ügyüknek kedves hőst és mártírt faragva belőle (Romsics I. 2014). A Dózsa-kultusz Románia szerte népszerű lett, számos román tudatában Dózsa román hősként él. A közvélekedésben napjainking megfigyelhető ez a leegyszerúsített kép, annak ellenére, hogy a kortárs történetírás igen kritikusan viszonyul Dózsa György személyéhez (ERDÉLYI G. 2014).

A szimbólumok körüli tulajdonlási verseny a banális nacionalizmus problematikusságának jó példája. BILLIG, M. (1995) nyomán a románosított utcanevek haszálata a román nacionalizmus banális megnyilvánulásának tekinthető, hiszen alacsony szimbolikus töltetű jelképekként a mindennapok során ugyanúgy a háttérben maradnak (vö. AZARYAHU, M. 2009). Ugyanakkor, ahogy azt MERriman, P.-Jones, R. (2009) kifejtette, a nemzeti kisebbségek a többségi társadalom banális nacionalizmusát gyakran forró nacionalizmusként értelmezik. Jelen esetben azonban többről lehet szó, mint román nemzeti szimbólumok egyszerú jelenlétéről. Dózsa, Kinizsi és Hunyadi neveinek románként való feltüntetése értelmezhető úgy, hogy a domináns nemzetiség képviselői megtagadják a magyar történelem szerves részét képező személyek magyar voltát, azért, hogy a románság történelméhez legjobb esetben is csak felületesen csatlakozó szimbólumokat faragjanak belölük. Ez egyrészt hátráltathatja e személyek konszolidáló szimbolikáját, mert elrománosításuk során olyan szimbolikus gyarapodáson mennek keresztül, amely részben alááshatja a magyarok számára kedves eredeti jelentést (vö. DwYER, O. J. 2004). Másrészt nehezebbé teheti a történelmi nevek szemantikus elmozdulását (egyszerú földrajzi névvé válását) is, gyengítve a toponímiára kivetített román múltértelmezés erejét (vö. AZARYAHU, M. 2009). Ugyanakkor e késő középkori történelmi személyek nemzetiségi hovatartozásáról folyó 
elit viták nem valószínú, hogy komolyabban befolyásolják a városi lakosság nagy részének róluk alkotott véleményét. Feltehetőleg a helyi románok és magyarok legalább nagy része mindhármójukat pozitív, de legalább is semleges szimbólumként értékeli, és ritkán gondol a nemzetiségi hovatartozásukat övezó értelmiségi vitákra.

A névsorban ellenpárt képeznek Bernády György és Dr. Emil Dandea marosvásárhelyi polgármesterek. A városépítőnek és modernizálónak is tartott Bernády György 1902-1912 és 1926-1929 között szolgált polgármesterként, munkássága alatt épült a belvárost meghatározó Közigazgatási Palota és Kultúrpalota. Személye a marosvásárhelyi magyar lokálpatriotizmus kulcsfigurája, alakja köré kisebb kultusz épült a rendszerváltás óta. Bernády nevének konszolidáló szerepét a románok számára csökkenti, hogy munkássága nagyrészét az Osztrák-Magyar Monarchia alatt fejtette ki, amikor még elenyésző számú román élt a városban. Ezért a nem tősgyökeres marosvásárhelyi románok számára nem jelent sokat Bernády György személye (GYÖRGY V. I. 2011). Bernádyval szemben ugyanakkor Dandea személye sokkal ellentmondásosabb. Bár Bernády mellett a másik modernizáló polgármesterként tartják számon, a város első román polgármestereként személyéhez füződik a román hatalmi reprezentáció meghonosítása a városban. Szolgálata alatt több román iskola kapott helyet a belvárosban, a városközpontban megépült az ortodox katedrális és a görög-katolikus templom, továbbá helyett kapott a dákoromán kontinuitást hirdető Latinitás Emlékmú valamint Avram Iancu szobra is (Marosvásárhely Polgármesteri Hivatala 2012). A városkép erószakos románosítása az ekkor még mindig túlnyomó többségében magyarok által lakott városban számos magyarban ellenszenvet váltott ki, emiatt Emil Dandea nem képes konszolidáló szerepet betölteni. Az eset arra mutat rá, hogy egy személy nemzeti hovatartozása felülírhatja az egyéb szempontok szerinti pozitív munkáját. Polgármesteri munkássága miatt hiába lenne helye a konszolidáló szimbólumok között, a magyarság szimbolikus és politika térvesztését okozó döntései miatt a magyarok számára feszültségkeltô szimbólumnak számít.

\section{Ellentmondásos megítélésú nevek}

Az egyes szimbolikus nevek ellentmondásosságának oka a névadók örökségéről alkotott, egymásnak ellentmondó magyar és román elitdiskurzusok. ZAHORÁN Cs. (2009) például a forgalomban lévő tankönyvek alapján mutatta be az uralkodó magyar és román emlékezetpolitikai narratívák ütközését, ami az újabb tankönyvek árnyaltabb szemlélete ellenére is fennáll. Tekintve, hogy a magyar és román történelemi narratívákban hangsúlyosak az egymás elleni küzdelmek (ZAHORÁN Cs. 2016), az ellentmondásos megítélésú szimbólumok jelenléte szinte garantált. Az itt ellentmondásosnak tekintett nevek olyan személyeket, eseményeket és eredetmítoszt örökítenek meg, amelyek fontos szerepet töltenek be a román nemzettudatban, de megítélésük gyakran lekicsinylő vagy ellenséges margyar forrásokban. Bár az ellenségkép-ápolás hagyományai miatt (ZAHORÁN Cs. 2016) előfordulhat, hogy egyes románok legalább némely szimbólumot (részben) magyarellenes értelmezésük miatt ünnepelnek, azt jelenleg nem tudjuk, hogy a magyarellenesség milyen mértékben befolyásolta az ellentmondásos szimbólumok kiválasztását, hiszen a névrajzban való szerepeltetésük lehet pusztán a helyi román elit nemzeti érzéseinek kifejeződésének eredménye is.

Az ellentmondásos nevek három csoportba oszthatók. Az első csoportba tartoznak a dákoromán kontinuitás elméletét hirdető nevek. Az elmélet lényege, hogy a mai románok ősei a dákoknak és a Dáciát meghódító rómaiaknak. Célja Erdély ősi román létének történelmi érvekkel való bizonyítása és a terület feletti román uralom legitimálása. Romániában az elmélet különböző változatai uralkodó felfogásnak számítanak, ugyanakkor a magyar történelemtudomány bizonyítékok hiányára hivatkozva elutasító álláspontot képvisel (PAPP 
L. 2009). A második csoportot a nagyromán egység megvalósításában közremúködő névadók alkotják. Ide sorolandók a 19. századi erdélyi román nacionalista politikusok; Erdély Romániához csatolására emlékeztető nevek; valamint az első világháború utáni román politikai hatalom első helyi letéteményesei. A róluk való megemlékezés gyakran ad okot vagy ürügyet az egymás elleni nacionalista mozgósításra (ZAHORÁN Cs. 2016).

A feszültséget gerjesztő nevek utolsó csoportját az erdélyi román felkelések vezérei alkotják. Mind az 1784-es, mind az 1848-49-es az erdélyi román nemzeti mozgalom jelképes eseményei. Az 1784-es felkelés mindhárom vezéréről, Horeáról, Cloșcáról és Crișanról is neveztek el utcát. Román narratívákban a felkelés gyakran antifeudális és nemzeti függetlenségi harcként szerepel, azonban magyar részről inkább nemes és nem ortodox-ellenes lázadásnak tekintik (GORUN-KovÁCs B.S. 2008). A román narratívák erejét mutatja, hogy 2020-ban a román parlament a román nép mártírjaivá és hôseivé nyilvánította Horeát, Cloșcát és Crișant (MÁRKOS I. Ö. 2020), míg magyar források gyakran magyarellenes és gyilkos jelzőkkel említik őket (pl. KÁDÁr GY.2010; SzUCHER E. 2017; MÁrKOS I. Ö. 2020).

Az 1848-as évi forradalmak fontos szerepet töltenek be a román nemzettudatban. Ezek közé tartozik az 1848-49-es erdélyi román felkelés, aminek szimbolikus jelentőségét mutatja, hogy vezetőjéről, Avram Iancuról utca és iskola, alvezéreiről, Constantin Romanu-Vivuról és Petru Dobráról utca van elnevezve. A román nemzeti történetírásban az esemény a román nemzeti szabadság melletti kiállásként él, ugyanakkor az (erdélyi) magyar szemszögből sokszor egyszerú lázadásként, a magyar szabadságharc elárulásaként tartják nyilván (GIDó Cs. 2010). A magyar szabadságharc leverését követően a felek ráadásul máig tartó számháborúba kezdtek a magyar és román áldozatok számát és fosztogatások mértékét illetően (BALOG, I. M. 2019).

Külön említésre érdemes az egyik kategóriába sem sorolható Vitéz Mihály fejedelem, aki 1600-ban rövid időre egyszerre töltötte be Havasalföld, Moldva és Erdély fejedelmi tisztségét. A fejedelem személye a román nemzeti narratíva egyik kulcsfontosságú figurája, benne látják a modern nagyromán egység első megvalósítóját (BURLACU, F. 2018). Ennek emlékére ot is a román nemzet mártírjának és hősének nyilvánította a román parlament (MÁRKOS I. Ö. 2020). „Románia elsó létrehozójának” narratíváját azonban nemcsak a nacionalista történetíráson kívüli román körökből érte kritika (a legismertebb BOIA, L. 2001), hanem magyar részről is elutasítóan lépnek fel vele szemben (pl. BíRó B. 2020; Köő A. 2020).

\section{Az alig létező toponímiai kétnyelvüség}

A marosvásárhelyi adatok megfelelnek azon országos helyzetet jellemző nemzetközi jelentéseknek, amik kifogásolják kétnyelvú utcanévtáblák jelentős hiányát a többnemzetiségú településeken (BETHLENDI A.-ToRó T. 2018). Az adatok elemzése során az utcákat aszerint csoportosítottam, hogy utcatábláik hány százaléka kétnyelvúsített típusa (utca, sugárút, sétány, tér, stb.) és neve szerint. A kutatás során megszámolt utcák 38\%-ban még csak az utcák típusának nevét sem írták ki két nyelven egyetlen egy utcanévtáblán sem (6. ábra). A kutatómunka során szerzett tapasztalatok alapján az ide tartozó utcák zöme a kommunista időszak alatt épült házgyári lakótelepeken található. Utcatípus kétnyelvüsége szempontjából a legnagyobb csoportot (46\%) a nagyjából fele részben kétnyelvúsített utcák jelentették. A kutatási tapasztalatok alapján ezek jellemzően kevés utcanévtáblával rendelkező kertvárosi utcák, ahol általában csak kettő-három utcanévtábla található. A helyi kétnyelvűség szemszögéből még lehangolóbb a helyzet amikor az utcanévtáblák tényleges kétnyelvűségét nézzük. Az összegyűjtött adatok alapján az utcák 86\%-a egyetlen egy kétnyelvúsített utcanévtáblát sem tartalmaz, míg az nagymértékben kétnyelvúsített utcák aránya csak 8\% (7. ábra). 


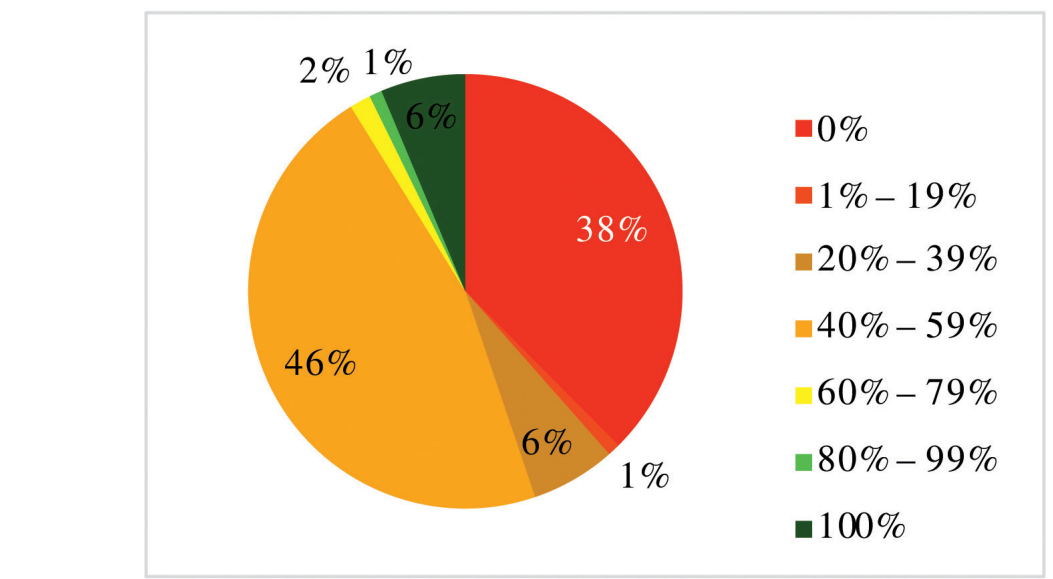

6. ábra Kétnyelvúsített utcák arányos eloszlása az utcatípus kétnyelvűsége szerint (mutatja, hogy az utcák hány \%-a, milyen arányban van felszerelve kétnyelvű utcanévtáblákkal)

Figure 6 Distribution of street name signs based on bilingualism of type

(shows the $\%$ of streets with a certain $\%$ of bilingual signs)

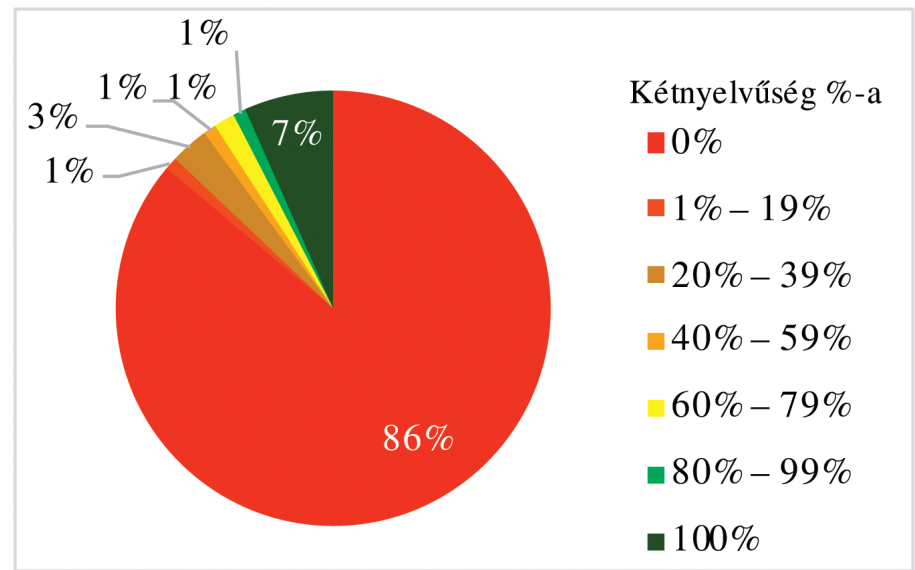

7. ábra Kétnyelvúsített utcák arányos eloszlása az utcanév kétnyelvűsége szerint (mutatja, hogy az utcák hány \%-a, milyen arányban van felszerelve kétnyelvú utcanévtáblákkal)

Figure 7 Distribution of street name signs based on bilingualism of name

(shows the $\%$ of streets with a certain $\%$ of bilingual signs)

Az utcanevek besorolásához megjegyezném, hogy míg az 1848 sétányt kétnyelvűnek, addig a személynevekről elnevezett utcákat egynyelvúnek könyveltem el. Véleményem szerint ugyanis ha az önkormányzat néhány utca esetében (pl. Dózsa György utca) kiíratta külön sorba a magyar és a román névváltozatot is, akkor ezt megteheti az összes személynévnél. Számos olyan jeles személy található az utcanévlistán, akik rendelkeznek a hivatalostól eltérő névalakkal valamely nemzetiség nyelvén (pl. Luther Márton esetében). Továbbá szintén sok személy rangjával, titulusával együtt szerepel a nyilvántartásban (pl. sg. maj. Ioan Roman), azonban egyikük rangja sem szerepel kétnyelvúsítve. Figyelembe véve az utcanevek kétnyelvúsítését kísérő vitákat, a fentiek véleményem szerint valószínúsítik, hogy a külön soros kiírás nélkülözése nem a külön magyar, ill. román névalak hiányában keresendő. 
Végezetül megemlítendő a magyar nyelv megjelenítési formája a kétnyelvúsített utcanévtáblákon. A magyar névalak a román névalakkal azonos betútípussal, színnel és méretben szerepel a táblákon. Rövid nevek esetén a román név után, hosszabbak esetében pedig a román név alatt kapnak helyet a magyar változatok. Ritkán előfordul a román és magyar egynyelvű utcatáblák együttes kitűzése egymás mellé vagy a magyaré a román alá. Figyelembe véve a román lakosság enyhe demográfiai többségét, a kétnyelvű utcanévtáblákon a kisebbségi nyelv reprezentációja nemzetközi kitekintésben is megfelelő, a nyelvek egyenrangúságát mutatja (AZARYAHU, M. 2012) - feltéve, ha ki vannak téve.

\section{Összefoglalás és következtetések}

A kutatás Marosvásárhely nemzetiségi erőviszonyait és nacionalizmusait vizsgálta a szimbolikus tájkép toponímiai elemeinek tanulmányozásával. A kritikai toponímia kutatások jellemzően vagy csak a szimbolikus toponímiai nevek elemzésére, vagy csak a toponímiai táblák többnyelvúségére összpontosítanak. Kutatásom ezért a két szempont együttes vizsgálatával pontosabb képet tudott alkotni a marosvásárhelyi toponímiai politizálás jelenlegi helyzetéről mintha csak önmagában vizsgálta volna a szempontokat.

Marosvásárhelyen a román szimbólumok fölénye jellemző a toponímiában. Ez a következtetés három megállapításon nyugszik: Először is kétszer annyi utca és ötször annyi oktatási intézmény rendelkezik román kötődésû szimbolikus névvel, mint magyarral. Ez jelentôs eltérést jelent a magyarok és románok demográfiai arányához képest. Ez tekinthetô a város két domináns nemzetisége közötti harrisoni (1995) értelemben vett terjeszkedési versenynek, mely során a románok jelentős pozíciókat foglaltak el a városi térben, lehetővé téve nacionalizmusuk hatékony kifejezését (JONES, R.-DESFORGES, L. 2003).

Másodszor a helyi román elit sikeresen rögzített a magyarok számára érzékeny szimbólumokat a névrajzba. Ez egyrészt megnyilvánul a Dózsa György, Kinizsi Pál és Mátyás király nemzeti hovatartozása körül folytatott tulajdonlási versenyben (HARRISON, S. 1995). Másrészt formát ölt a magyar részrôl ellentmondásos megítélésú elismert román személyek alkalmazásában, melyekhez hasonló kaliberű magyar személyek hiányoznak a toponímiából. Ugyanis ezen utcanevek hiába a román nacionalizmus banális megnyilvánulásai, a kisebbségben lévő magyarok számára a forró nacionalizmus jelei (MERRIMAN, P.-JONES, R. 2009; JONES, R.-MERRIMAn, P. 2009). Tekintve, hogy a helyi román névrajz szimbolikus politikája elsősorban erdélyi és országos kötődésú, valamint jelentőségú személyekre támaszkodik, a román nemzetiesító állam nacionalizmusának helyi megnyilvánulásaként, annak minimális módosításokkal átvett változatának értelmezhető. Ez megerősíti JoNES, R.-Desforges, L. (2003) és Jones, R.-Fowler, C. (2007) megállapításait a helyi és országos (banális) nacionalista politika kapcsolatáról.

A román szimbolikus dominanciára utal továbbá, a részben vagy egészen kétnyelvúsített utcák alacsony száma is. A teljes egészében kétnyelvüsített utcák 7\%-os aránya egyértelmúen a magyar nyelv jelenlétének tudatos elnyomására utal. Vagyis a helyi magyarság gyenge érdekérvényesítő képességgel rendelkezik, annak ellenére, hogy regionális szinten is jelentős szimbolikus ügyről van szó (vö. BRUBAKER, R. 1996). A toponímiai kétnyelvúség majdnem teljes hiánya emellett beleilleszkedik a korábbi kutatások által meghatározott romániai trendekhez (ZAHORÁN Cs. 2016; BETHLENDI A.-TORÓ T. 2018).

A román szimbolikus erőfölény mellett a toponímia alapján a román és magyar nacionalizmusok különbözőségére is következtethetünk, ami megerősíti a BRUBAKER, R. (1996) féle nacionalista triád által sugalltakat. Egyrészt a helyi román toponímiai tájkép nacionalizmusa megegyeztethető a központi nemzetiesítő nacionalizmussal a konfliktu- 
sos és/vagy helyi illetőséggel nem rendelkező személyek széles körú használata miatt. Másrészt magyar részról a névrajzot a helyi és erdélyi elemek túlsúlya jellemzi, amely által a marosvásárhelyi toponímia a magyarországitól eltérő, erdélyi magyar kisebbségi nacionalizmust jelenít meg.

Ugyanakkor kutatási eredményeimet érdemes bizonyos fenntartásokkal kezelni. Egyrészt, dolgozatom csak a szimbolikus tájkép toponímiai elemeivel foglalkozott, ezért megállapításim részlegesek és további kutatást igényelnek. A szimbolikus tájkép egyéb elemeinek megvizsgálása megerősítheti de akár meg is cáfolhatja következtetéseimet. Másrészt, a jelen elemzésben kipróbált Google utcaképek a tudományterületen eddig még nem használt módszerként lett kipróbálva. Tapasztalataim alapján hasznos eszköz lehet a jövőben, feltéve, hogy a vizsgálat tárgyát jelentős, nagy népességú városok képezik, melyek sok (viszonylag) friss adattal rendelkeznek. Ebből a szempontból Marosvásárhely nem volt feltétlenül ideális, mert az utcák 17\% nem szerepelt a Google adatbázisában, valamint az utcák többsége régi, 2012-es utcaképekkel rendelkezik csak. Harmadrészt, a kutatás objektivitása ellen szól a szimbolikus utcanevek politikai hozzáállása alapján történő besorolása közben gyakorlott szubjektív értékítéletem. A helyi lakosság szimbolikus értékrendjét vizsgáló kutatások hiányában csak másodlagos, közvetett forrásokra és személyes belátásomra tudtam hagyatkozni, melyek valamelyest bizonytalan besorolást eredményeztek és az értelmiségi elitek szempontjait jelenítették meg. Ez etnikai földrajzi szempontból nehézzé és bizonytalanná teszi a települések szimbolikus tájképének kielemzését. Ezért érdemes lenne jövőbeli szociológia vizsgálatok során külön vizsgálni a szimbólummá vált személyek, események, valamint a nemzeti identitás és nemzetek egymáshoz való viszonyát. Ez nemcsak az emlékezetpolitika jobb megértését segítené elő, hanem emellett jelentősen csökkentené a szubjektív értékítélet szerepét a szimbolikus földrajzi kutatásokban is.

Végezetül kutatási eredményeim a toponímiának csak a 2012-2019 közötti helyzetét tárják fel. Ezért a kutatás egy hosszabb projekt első lépésének tekinthető, melyet az okozati tényezőkre összpontosító kvalitatív kutatással és más városokat is magába foglaló összehasonlító, kvantitatív vizsgálatokkal lenne érdemes folytani. Kvalitatív kutatások kiemelten fontosak lennének a tanulmányban felvetett számos kérdés megválaszolására. Emellett megfontolandó a sikeres együttmúködés helyeinek tanulmányozása a jó szimbolikus politikai gyakorlatok elsajátítása végett. Szintén érdemes lenne néhány év múlva újra megvizsgálni a marosvásárhelyi helyzetet. Ugyanis 2020. szeptemberében 20 év után először magyar polgármestert választottak a város élére, aki megfogadta a toponímiai kétnyelvűség megteremtését. Sikere vagy bukása értékes ismeretekkel szolgálhat a helyi politika természetét illetően, illetve a helyi lépték a romániai kisebbségpolitikai rendszeren belüli jelentőségének felmérésében.

\section{Köszönetnyilvánítás}

A szerző köszönetét fejezi ki BotTLIK Zsoltnak, DürR MikLósnak, PHILIP STEINBERGnek a tanulmány elkészítéséhez nyújtott szakmai segítségükért.

HOLÁNyi ÁKOS

Durhami Egyetem, Földrajzi Tanszék, Durham (UK)

akos.holanyi@dunelm.org.uk 


\section{IRODALOM}

AzARYAhU, M. 1996: The power of commemorative street names. - Environment and Planning D: Society and Space 14. pp. 311-330.

Azaryahu, M. 2009: Naming the Past: The Significance of Commemorative Street Names. - In. Berg L. D. - Vuolteenaho J. (szerk.): Critical Toponymies, The Contested Politics of Place Naming. Ashgate, Farnham and Burlington, VT. pp. 53-70.

AzARYAHU, M. 2012: Hebrew, Arabic, English: the politics of multilingual street signs in Israeli cities. - Social \& Cultural Geography 13. 5. pp. 461-479.

BALOG, I. M. 2019: Revoluția de la 1848-1849 în Transilvania: vechi și noi controverse istoriografice. - Anuarul Institutului de Istorie »George Bariţiu«-Series HISTORICA 58. 58. pp. 73-81.

BAROCH Cs. 2019: Szimbolikus politikai fordulatok és térbeli mintázataik: közterületek átnevezése Budapest I. és V. Kerületében. - Földrajzi Közlemények 143. 2. pp. 144-157.

BAROch Cs.-BERKi M. 2018: Lwów, Lemberg, Lvov, Lviv - Az „oroszlánok városa” mint palimpszeszt, - In. KöSzEGi M.-BARTA G.-Illés T.-BERKi M. (szerk.): Etnikai földrajzi kutatások a posztszovjet térségben. Eötvös Loránd Tudományegyetem, Természettudományi Kar, Budapest. pp. 191-210.

Bartos-Elekes Zs. (2016) A hatalom névrajza - A névrajz hatalma. - Földrajzi Közlemények 140.2.pp. $124-134$.

Bethlendi A.-Toró T. 2018: A peculiar case of monitoring. Minority rights in Romania as seen through the lens of the ACFC and the COMEX. - Hungarian Journal of Minority Studies. 2. pp. 23-61.

BiLlig, M. 1995: Banal Nationalism. Sage, London. 200 p.

BíRó B. 2020: Vitéz Mihály és a székely autonómia az emberjogi bizottságban. - Székelyhon.ro, június 10. [online] Elérhető: https://szekelyhon.ro/vilag/vitez-mihaly-es-a-szekely-autonomia-az-emberjogibizottsagban\# (megtekintve: 2021. 04. 15.)

BoIA, L. 2001: History and Myth in Romanian Consciousness. Central European University Press, Budapest. 285 p.

BottLik, Zs. 2017: A Divided Townscape? Ethnic Segregation in Bosnia and Herzegovina - the Mostar Case. - Social Studies 14. 1. pp. 71-93.

BotTLIK Zs. 2018: Változó hatalom, változó városi tér - a politika lenyomatai Chișinău-ban. - In. KôszEGI M.-BARTA G.-Illés T.-BERKI M. (szerk.): Etnikai földrajzi kutatások a posztszovjet térségben. Eötvös Loránd Tudományegyetem, Természettudományi Kar, Budapest. pp. 211-228.

BrubakeR, R. 1996: Nationalism Reframed. Nationhood and the National Question in the New Europe. Cambridge University Press, Cambridge. 202 p.

Burlacu, F. 2018: The role of reign in asserting the Romanian statehood in school textbooks from the Romanian medieval states to the Romanian national state. - Euromentor Journal 9. 4. pp. 16-27.

Civil Elkötelezettség Mozgalom 2014: Iskolai homlokzati táblák kétnyelvúsítése Marosvásárhelyen. [online] Elérhető: https://cemo.ro/iskolai-homlokzati-tablak-ketnyelvusitese-marosvasarhelyen/ (megtekintve: 2021.04. 15.)

Civil Elkötelezettség Mozgalom 2017: Stratégiai pereink a kétnyelvű utcanévtáblák hiánya miatt. [online] Elérhető: https://cemo.ro/strategiai-pereink-a-ketnyelvu-utcanevtablak-hianya-miatt/ (megtekintve: 2021.04. 15.)

Cohen, S.B.-KLiot N. 1992: Place-Names in Israel's Ideological Struggle over the Administered Territories. - Annals of the Association of American Geographers 82. 4. pp. 653-680.

Dragoman, D. 2011: Ethnic groups in symbolic conflict: the „ethnicisation” of public space in Romania. Studia Politica: Romanian Political Science Review 11. 1. pp. 105-121.

DWYER, O. J. 2004: Symbolic accretion and commemoration. - Social and Cultural Geographies 5. 3. pp. 419-435.

ERDÉLYI G. 2014: Egy felkelés arcai, avagy miért kell nekünk Dózsa? - Történelmi Szemle 56. 4. pp. 539 -547.

Erdélyi Magyar Adatbank n.d.: Erdélyi etnikai és felekezeti statisztikái a népszámlálási adatok alapján, 18522011. Varga E. Árpád 2002-től kiegészített adatsorai. [online] Elérhető: https://nepszamlalas.adatbank.transindex.ro (megtekintve 2021. 04. 15.)

ERôss Á. 2017: Politics of street names and the reinvention of local heritage in the contested urban space of Oradea. - Hungarian Geographical Bulletin 66. 4. pp. 353-367.

ERŐSS Á.-TÁTRAI P. 2010: Ethnic features of symbolic appropriation of public space in changing geopolitical frames - the case of Oradea/Nagyvárad. - Hungarian Geographical Bulletin 59. 1. pp. 51-68.

Gidó Cs. 2010: Nemzetek egymás mellett és ellen az 1848-49-es forradalom idején. Transindex.ro, március 14. [online] Elérhető: https://itthon.transindex.ro/?cikk=11100 (megtekintve: 2021. 04. 15.)

Gorun-Kovács B.S. 2008: A Horea-felkelés és magyarországi forrásai. PhD Disszertáció, Debreceni Egyetem, Magyarország. 208 p.

GyÖRGY V. I. 2011: A tér szimbolikus birtoklása Marosvásárhelyen. - Pro Minoritate 20. 4. pp. 40-53.

HARrison, S. 1995: Four Types of Symbolic Conflict. - The Journal of the Royal Anthropological Institute 1. 2. pp. 255-272. 
Jones, R.-Desforges, L. 2003: Localities and the reproduction of Welsh nationalism. - Political Geography 22. 3. pp. 271-292.

JONES, R.-FowLER, C. 2007: Placing and scaling the nation. - Environment and Planning D: Society and Space 25. 2. pp. 332-354.

Jones, R.-MERriman, P. 2009: Hot, banal and everyday nationalism: Bilingual road signs in Wales. - Political Geography 28. 3. pp. 164-173.

KÁdÁR Gy. 2010: Mit jelent Horea, Cloşca és Crişan neve? Történelem Portál, május 22. [online] Elérhető: https://tortenelemportal.hu/2010/05/mit-jelent-horea-closca-es-crisan-neve/ (megtekintve: 2021.04. 15.)

KÁDÁR Gy. 2011: Mátyás „román király” és a „román vezérek” Háromszék, február 26. [online] Elérheto: https://www.3szek.ro/load/cikk/36970/matyas_,roman_kiraly”_es_a_,roman_vezerek”_2 (megtekintve: 2021. 04. 15.)

Köő A. 2020: Seholsincs Románia fejedelme: Vitéz Mihály mítosza. - Magyarságkutató Intézet, július 7. [online] Elérhető:

https://mki.gov.hu/hu/hirek/seholsincs-romania-fejedelme-vitez-mihaly-mitosza (megtekintve: 2021.04. 15.)

LÁsZLó M.-NovÁK Cs. Z. 2012: A szabadság terhe. Marosvásárhely, 1990. március 16-21. Pro-Print Kiadó, Csíkszereda. 286 p.

MÁrkos I. Ö. 2020: A román parlament magyarellenes történelmi személyiségeket nyilvánított hősnek és mártírnak. Origó.hu, július 1. [online] Elérhető:

https://www.origo.hu/nagyvilag/20200701-magyarellenesek-lettek-hosok-es-martirok.html (megtekintve 2021. 04. 15.)

Marosvásárhely Polgármesteri Hivatala 2012: Emil Dandea emlékére. [online] Elérhető: https://www.tirgumures. ro/index.php?option=com_content\&view=article\&id=1941\&Itemid=1\&lang=hu (megtekintve: 2021.04 . 15.)

Maszol.ro 2015: Mégsem lesz minden utca kétnyelvű Marosvásárhelyen? Maszol.ro, október 21. [online] Elérhető: https://www.maszol.ro/index.php/tarsadalom/54811-megsem-lesz-minden-utca-ketnyelvmarosvasarhelyen (megtekintve 2021. 01. 06.)

McDowell, S. 2008: Heritage, Memory and Identity. - In. Graham, B.-Howard, P. (szerk.): The Ashgate Research Companion to Heritage and Identity. Ashgate, Aldershot and Burlington, VT. pp. 37-53.

Merriman, P.-Jones, R. 2009: 'Symbols of Justice': the Welsh Language Society's campaign for bilingual road signs in Wales, 1967-1980. - Journal of Historical Geography 35. 2. pp. 350-375.

Mitchell, K. 2003: Monuments, Memorials, and the Politics of Memory. - Urban Geography 24. 5.pp. $442-459$.

NorA, P. 1989: Between Memory and History: Les Lieux de Mémoire. - Representations 26. 1. pp. 7.24.

PAPP L. 2009: A dákoromán mítoszok nyomában. Múlt-kor, május 4. [online] Elérhető: https://mult-kor.hu/20090504_a_dakoroman_mitoszok_nyomaban?pIdx=3 (megtekintve 2021. 04. 15.)

Ravio, P. 1998: Politics of memory: Historical Battlefields and Sense of Place. - Nordia Geographical Publications 27. 1. pp. 59-66.

Romsics I. 2014: Székely Dózsa György: Haramia és/vagy népvezér? Rubikon 24. 3. pp. 4-29.

Rose-Redwood, R.-Alderman, D.-Azaryahu, M. 2010: Geographies of toponymic inscription: new directions in critical place-name studies. - Progress in Human Geography 34. 4. pp. 453-470.

SAID, E. 2000: Invention, Memory, and Place. - Critical Inquiry 26. 2. pp. 175-192.

SzUCHER E. 2017: Romokból feltápászkodó kisnemesek. Erdélyi Napló, szeptember 22. [online] Elérhető: https://erdelyinaplo.ro/aktualis/riportok/romokbol-feltapaszkodo-kisnemesek\# (megtekintve: 2021.04. 15.)

Till, K. E. 2003: Places of Memory. - In. Agnew, J.-Mitchell, K.-ToAl, G. (szerk.): A Companion to Political Geography. Routledge, Malden, MA; Oxford and Carlton, Victoria. pp. 289-301.

Tohaneanu, T. 2017: Istoria lui Pavel Chinezu, conducătorul de oști cu forță herculeană din Transilvania a cărui faimă de războinic a ajuns până la Vatican. Cunoastelumea.ro, július 9. [online] Elérhető: http://www.cunoastelumea.ro/istoria-lui-pavel-chinezu-conducatorul-de-osti-din-transilvania-a-caruifaima-de-razboinic-a-ajuns-pana-la-vatican-avea-o-forta-herculeana/ (megtekintve: 2021. 04. 15.)

Tolia-Kelly, D. P. 2013: Landscape and memory. - In. HowArd, P.-ThomPson, I.-WATERTON, E. (szerk.): The Routledge Companion to Landscape Studies. Routledge: London and New York. pp. 322-334.

VERES V. 2005: Az erdélyi magyarok nemzeti identitása a társadalmi és az etnikai struktúra összefüggésrendszerében (2000). - Erdélyi Társadalom 3. 1. pp. 71-96.

VERES V. 2008: Az erdélyi magyarok természetes nemzeti identitásának fő vonásai a Kárpát panel 2007 tükrében. - Erdélyi Társadalom 6. 1-2.pp. 67-89.

WyLIE, J. 2007: Landscape. Routledge: London. 246 p.

ZAHORÁN Cs. 2009: Konklúzió: nemzeti- vagy nemzetállami nézőpont? Múlt-kor, május 24. [online] Elérhető: https://mult-kor.hu/20090524_konkluzio_nemzeti_vagy_nemzetallami_nezopont (megtekintve: 2021. 04. 15.)

ZAHORÁN Cs. 2016: Trikolórok, farkasok és turulok földje. Magyar és román szimbolikus gyakorlatok Erdélyben 1989 után. - Regio 24. 1. pp. 226-281. 